\title{
Are Service Firms Affected by Exchange Rate Movements?
}

\author{
Jen Baggs ${ }^{*}$, Eugene Beaulieu ${ }^{\circ}$ and Loretta Fung ${ }^{+}$
}

September 8, 2008

\begin{abstract}
There is a growing literature addressing the effects of exchange rate movements on manufacturing firms, but little similar analysis concerning firms in the service sector. As the service sector is the largest component of the Canadian economy and services are becoming increasingly tradable, the implication of international economy on service sector firms is an important, yet rarely explored, research question. This paper addresses the question by analyzing the effects of industry specific real exchange rate movements on the profitability, survival and sales of Canadian service sector firms. Using rich firm-level data that covers the universe of incorporated firms in Canada and service trade data, our empirical results show that real appreciations of the Canadian dollar reduce firm probability of survival, sales and profitability while depreciations have the opposite effect (a separate abstract on firm-level data is attached). In addition, the negative effect of real currency appreciations on firm survival is less pronounced for more productive firms. Our findings suggest a significant exchange rate effect on service firms similar to that found for manufacturing firms in earlier studies by Baggs and Brander (2006) and Baggs, Beaulieu and Fung (2009). When comparing the economic magnitude of the exchange rate effects on service sector firms to the effects on manufacturing firms, we find that, when facing an identical movement of the value of the Canadian dollar from the highest to the lowest level, service sector firms experience smaller increase in profit and sales but larger increase in probability of survival as compared to manufacturing firms.
\end{abstract}

Acknowledgements: We are extremely grateful to Statistics Canada, in particular the Business and Labour Market Analysis and the Balance of Payments divisions, and especially Garnett Picot, for access to the firm level data used in this paper. The paper has benefited from comments by Ben Tomlin and Constance Smith, and from seminar participants at the 2008 Canadian Economics Association meetings, Statistics Canada and the 2008 World Congress on National Accounts and Economic Performance Measures for Nations. Financial support from SSRHC is gratefully acknowledged. Loretta Fung acknowledges the financial support from Statistics Canada post-doctoral program and from the Department of Economics, University of Alberta.

\footnotetext{
*Faculty of Business, University of Victoria. jenbaggs@uvic.ca

${ }^{\circ}$ Department of Economics, University of Calgary. beaulieu@ucalgary.ca

${ }^{+}$[Corresponding author] Department of Economics, University of Alberta and National Tsing Hua University. Email: loretta.fung@ualberta.ca. Tel: (780) 221-6697.
} 


\section{Data Abstract - the T2LEAP}

The data set used in our study is the T2LEAP database. T2LEAP, created by Statistics Canada, is a unique firm-level database that is the universe of incorporated firms that file a tax return and hire employees in Canada. The current version of the database covers the year 1984 to 1998. T2LEAP is a merger of two Canadian administrative databases. The first database, the Longitudinal Employment Analysis Project (LEAP), is used to identify de novo entry and exit, industry classification (at the 3-digit SIC level), and the number of employees. The second database is the Corporate Tax Statistical Universe File (T2SUF). This database is used to assess firm specific annual financial variables such as profit, debt, equity, assets, sales and location. The employment record of each business is derived from administrative taxation records that each Canadian employer must file. The payroll data are associated with a Revenue Canada employer identification number. Firms enter into the LEAP database in the year they first hire employees (should they enter after 1984), and record their last entry in the database in the last year they have employees (should they exit before 1998). For each year, total payroll and employment are calculated. The latter is the average annual number of employees within the firm, or Average Labor Units (ALU). Measured by either output or employment, the database includes almost the entire Canadian private sector. The omitted components are non-incorporated enterprises and corporations that hired no employees.

The T2LEAP data is ideal for identifying firm entry and exit because of its universal coverage. We are able to identify the year of birth and the year of death using Baggs' (2005) criteria. Specifically, a panel of survivors and exitors is developed using the following method. The initial population of firms are those existed in 1986. The sample is augmented in each consecutive year by removing exits and adding entrants. A firm is removed from the sample in year $t$ if year $t$ is the year when it files its last tax return (the T2SUF measure of exit) or if year $t$ is the last year when it employs workers (the LEAP measure of exit). If a firm falls into either of these categories, it is considered exiting. A firm enters our sample in the first year it both employs workers and files a tax return.

An important advantage of the T2LEAP data is its complete coverage of all incorporated Canadian firms. It comprises both publicly-traded and privately-held firms (which consist of a larger portion of the Canadian business sector). The dataset not only contains manufacturing but also retail and service sector firms. The inclusion of service sector firms provides us a rare opportunity to examine their behaviour and to make comparison between service and manufacturing firms. In addition, the inclusion of small firms makes it possible to analyze the financial position of small firms and their survival. For a complete list of published papers that have used the T2LEAP see http://mypage.iu.edu/ kphuynh/fdt2leap/t2leap_bib.pdf. 


\section{Introduction}

Services have long been considered by economists and other observers of international commerce to be the proverbial non-traded good. Indeed, by conventional measures of openness services remain the most closed sector of the world economy. However, in part due to the technological changes that have made some services more "tradable", services have increased their importance in international trade. International trade and investment in the service sector have been growing rapidly over the past twenty years and in 2005 worldwide service exports were valued at \$2.4 trillion Canadian dollars. ${ }^{1}$ The growth of international outsourcing of some service activities has attracted considerable media attention in the developed world as white-collar workers in the service sector face increased international competition. At the same time, services have become the largest component of the "post-industrial" developed world economies. According to UNCTAD (2004, p. 97), services represent 72 percent of GDP in developed countries and 52 percent in developing countries. Moreover, services are crucial inputs into the production of most goods. Even if some services are not traded, they may rely on tradable inputs. This relationship with tradable inputs implies that service sector firms may be significantly, if indirectly, influenced by international economic conditions.

Given the important role of services in the economy, the dearth of studies on services is a major omission in the economics literature. There is an emerging literature on trade in services, but the implications of the international economy on the service sector firms have not been well developed in the literature and are not well understood. For example, we are not aware of any studies that examine the impact of trade liberalization on the service sector. On the other hand, studies examining the impact of trade liberalization on the manufacturing sector are ubiquitous. Similarly, there are a number of studies examining the impact of exchange rates on the manufacturing firms but few examine the implications of the exchange rate for service sector firms, the topic we address in this paper. ${ }^{2}$ Limiting investigation to

\footnotetext{
${ }^{1}$ Export Development Corporation Report on Services accessed July 14, 2008: https://www.edc.ca/english/docs/news/2006/mediaroom_11409.htm

${ }^{2}$ One of the few important studies of the exchange rate effects on service industries is the research by Campbell and Lapham (2004). It examines the effects of real exchange rate changes on the industry dynamics for four retail trade industries located close to the US-Canada border.
} 
manufacturing industries restricts our understanding of the impact of exchange rates to less than 30 percent of the economies of most developed countries. This is a major omission. Moreover, using US data, Foote (1998) provides strong evidence that firm dynamics are very different in non-manufacturing sectors, underscoring the importance of investigating firms in the service sector directly.

There are three main reasons that services have been overlooked in the literature. First, services have until recently been left off of the table in negotiations over international trade liberalization. Therefore, it is natural to focus on understanding the impact on the manufacturing sector that was affected directly by tariff reductions. Second, tariffs and tariff data typically do not exist for service industries. Third, the majority of the studies examining the impact of trade policy are based on data from the manufacturing sector as many of the data sources focus exclusively on manufacturing industries.

Building on both the services trade literature and the work on how changing international conditions affect domestic firms, this paper examines how fluctuations in the real exchange rate affect the profits, survival and sales of service sector firms. These three variables have been shown to be significantly affected by both tariffs and exchange rates in manufacturing firms. Baldwin and Krugman (1989) suggest significant consequences of the exchange rate for both entry and exit. Papers by Baggs (2005), Pavcnik (2002), and Lewis-Bynoe, Griffith and Moore (2002) investigate the effect of trade liberalization on exit. Baggs et. al. (2009) found that domestic currency appreciations negatively affected the survival of manufacturing firms, as well as decreasing their sales. Mann (1986) demonstrates a significant relationship between profits and exchange rates, as does Clarida (1991) who finds that real exchange rate fluctuations have considerable implications for the profits of US manufacturing firms, even when controlling for output, costs and relative prices.

We circumvent the absence of tariff data and the complexity of measuring trade liberalization for service firms, by considering exchange rates rather than tariffs. Indubitably trade liberalizations (tariff concessions) are different from changes in exchange rates. Tariff changes are often permanent and often mandated by trade policy negotiations while exchange rate fluctuations may be transient. However, as Feenstra (1989) points out, large exchange rate movements may have effects that are comparable to the 
effects of significant episodes of tariff changes by similarly altering the competitive position of domestic firms in the international economy. Both tariffs and exchange rates change the competitive conditions of domestic firms relative to foreign competitors and accordingly offer a window into the implications of an increasing openness. An exchange rate appreciation, for example, can be regarded as reverse trade liberalization for exporters (i.e. commensurate to an increase in export tariffs), but generates effects similar to trade liberalization for import competing firms by making imports less expensive to domestic consumers.

Our empirical strategy, then, is to examine the impact of movements in the real exchange rate on three variables reflecting firm behaviour. We construct a trade-weighted real exchange rate at the industry level using data on services sector exports and imports to identify the exposure of firms to the fluctuations of different currencies. We merge our trade-weighted real exchange rate variable with firm level data from Statistics Canada's T2-LEAP dataset. T2-LEAP is an excellent longitudinal firm level dataset containing the tax records of all incorporated Canadian firms hiring employees, allowing us to pursue a comprehensive analysis of the service sector. These data cover all sectors of the Canadian economy, both public and privately held firms, and firms of all sizes and financial structures. Using these data, we examine the impact of large real exchange rate movements on the profits, survival and sales of firms in the service sector. In the fifth section of the paper, we are able to use the same data set to compare the implications of the exchange rate for service firms and manufacturing firms.

In addition to the availability of excellent data, the use of Canadian firms in our study affords a number of advantages. First, we are able to combine our firm level service sector data with a period of time (1986-1997) in which the Canadian dollar experienced both sustained appreciations and depreciations of a similar magnitude. These fluctuations offer an excellent opportunity to examine the effects of large real exchange rate changes on service sector firms. Second, Canada is a small open economy and services are important to the Canadian economy and increasingly traded. Copeland (2002) indicates that 73 percent of Canadian employment is in the service sector. In 2005, services accounted for 
$16 \%$ of Canadian exports, and $18 \%$ of imports (by value) ${ }^{3}$. Service trade is also exhibiting considerable growth. Between 2000 and 2005, Canadian service sector exports grew by $12 \%$ and imports by $21 \%$. Services are now the third largest export sector in Canada. The Canadian service sector is both substantial and relatively representative of other developed countries in terms of magnitude.

Our empirical results indicate that real appreciations of the Canadian dollar reduce firm profitability, probability of survival and sales while depreciations have the opposite effect. Overall, our findings suggest a significant effect on service firms, the direction of which is similar to that of manufacturing firms found in Baggs et. al. (2009). The next section details our theoretical motivation and the third section describes the data. The empirical results are found in the fourth section and the fifth section compares the statistical and economic size of our results with those for the manufacturing sector. The sixth section concludes.

\section{Theoretical Motivation}

Given the increasing openness of the service sector, it is becoming gradually more reasonable to expect trade liberalization and exchange rate changes to affect service firms in manners similar to manufacturing firms. Theoretically, most models do not differentiate between manufacturing and services, they differentiate between "traded" and "non-traded". To the extent that services are indeed traded, they increasingly fall into the same theoretical structures as do manufacturing firms.

For any traded product (including services), we might in general expect home currency appreciations to increase the amount of competition domestic firms face from (now cheaper) imports, and reduce their competitive edge in foreign markets as their exported products become relatively more expensive. Similarly, a domestic currency depreciation improves the competitive position of domestic firms both at home and abroad. This idea is formalized in Fung's (2008) model which builds on the Krugman (1979) monopolistic competition model by adding an exchange rate variable. In this model, labour is the only factor of production. Therefore, a domestic currency appreciation lowers the relative

\footnotetext{
${ }^{3}$ In 2005 Canadian service exports were valued at $\$ 69,979$ million Canadian dollars and imports at $\$ 79,141$ million Canadian dollars. In the same year merchandise trade exports were valued at $\mathrm{C} \$ 436,225$ million and imports at C $\$ 380,809$ million. For further details see: http://www.dfait-maeci.gc.ca/eet/pdf/Pfact_Services_Sep_2007a-en.pdf
} 
cost of foreign firms in terms of domestic currency units, causing domestic firms to face increased competition in both domestic and export markets. ${ }^{4}$ Domestic firms must reduce their mark-up to remain competitive. Assuming all the costs are domestic, profits of domestic firms will also decrease. For some firms, this increase in competition and consequent fall in price and profits will lead them to exit. In Fung's model, firms are assumed to be homogeneous in productivity and an appreciation in the domestic currency is predicted to result in a reduction in the number of domestic firms. Combining this model with Melitz and Ottaviano's (2008) model with firm heterogeneity, we expect that the intensified competition caused by a domestic currency appreciation will drive less productive firms out of business. A mechanism similar to this is discussed in Bernard et al (2003). ${ }^{5}$

As for the sales of surviving domestic firms, Fung (2008) shows two countervailing effects of an exchange rate appreciation on the sales (to both domestic and foreign markets). While the cost disadvantage faced by domestic firms reduces their sales, the death of other firms leaves the surviving firms with a larger market share. Consequently, from a theoretical perspective, the direction and relative magnitude of the changes in exports and domestic sales determines the net effect of a currency appreciation on a surviving firm's sales. ${ }^{6}$ If the exit rate is low or the exiting firms are substantially smaller than the incumbent firms, a domestic currency appreciation is expected to reduce the sales of surviving firms. ${ }^{7}$

Testable Hypotheses

The theoretical considerations described above yield three hypotheses which we will explore

\footnotetext{
${ }^{4}$ The demand function in Fung's (2008) model is derived from a symmetric translog expenditure function. It was used in studies such as Bergin and Feenstra $(2000,2001)$ and Feenstra (2003). In this model, the (positive) price elasticity of demand is positively associated with the relative price of the good to its competing goods. Compared to the demand function derived from a CES utility function (that usually results in constant mark-ups), the advantage of using this demand function is that, after taking production decisions into account, a reduction in the price of competing goods can lead to a pro-competitive reduction of mark-ups.

${ }^{5}$ In Bernard et al (2003), the effects of appreciations of the US dollar on the US economy is approximated by an increase in the US wage.

${ }^{6}$ For surviving firms' exports, the effect of the cost disadvantage is more likely to outweigh the effect of increased market shares, resulting in a reduction in exports. However, the effect on domestic sales depends on the relative magnitude of the cost disadvantage and market share effects.

${ }^{7}$ Conversely, if the exit rate is high or exiting firms are large, market share gains from the death of other firms may be greater than the sales reduction caused by intensified foreign competition. Therefore, it is possible that a domestic currency appreciation may cause an increase in the sales of surviving firms.
} 
empirically. All three hypotheses are stated in terms of an appreciation but a depreciation would have the opposite effect.

1) A domestic currency appreciation reduces the mark-up domestic firms charge, lowering their profits.

2) An appreciation of the domestic currency reduces a domestic firm's probability of survival and this negative effect is less pronounced for more productive firms.

3) A domestic currency appreciation will cause a reduction in total sales.

Note that in theory, a domestic currency appreciation has an ambiguous effect on a firm's total sales. In the Canadian service sector, it is more likely that a domestic currency appreciation will cause a reduction in sales given that the exit (entry) rate is low and the exiting firms are substantially smaller than surviving firms. ${ }^{8}$

\section{Data}

\subsection{Micro data}

This paper examines the effects of exchange rate movements on the performance of service firms that are exposed to international trade in services. The limited availability of service trade data restricts our analysis to communication, finance and insurance, real estate and insurance agent, business services, and part of other services. ${ }^{9}$ However, we have a very rich dataset on firms which is known as the T2LEAP data. T2-LEAP is a detailed longitudinal micro-data set produced by Statistics Canada. This data set is ideal for analyzing the behaviour of service firms and testing our three hypotheses described in the previous section. It was created by linking two underlying sources of data: corporate tax information from "T2" tax forms, and the Longitudinal Employment Analysis Project (LEAP), which obtains its data from firm-specific payroll information filed with the Canada Revenue Agency (CRA). Firm names are removed and replaced with numerical identifiers to make the data set anonymous.

T2-LEAP is a longitudinal dataset that provides information on every incorporated Canadian

\footnotetext{
${ }^{8}$ The annual exit rate is approximately 6 percent and the surviving firms are on average three times larger than the exiting firms in terms of the number of employees.

${ }^{9}$ Central bank, government service, medical and social service and part of other services (such as membership organization services) are excluded from the analysis as these industries are not affected by economic conditions. Transportation, wholesale trade, retail trade, and accommodation, food and beverage service industries are excluded due to the lack of trade data.
} 
establishment $^{10}$ that legally hires employees (and hence files payroll information with the CRA) AND, in the same year, files a "T2" corporate income tax return. T2-LEAP covers the period 1984 through 1998, and for the purposes of this study data from 1986-1997 are used. ${ }^{11}$ It provides annual firm-level data documenting the firm's employment level, profit, revenues, debt, equity, assets, location, and industry affiliation at the 3-digit Standard Industrial Classification-Establishment (SIC-E) level. The dataset contains almost the entire Canadian private sector as measured by either output or employment. Components of the economy that are omitted include non-incorporated enterprises and corporations that hired no employees.

An important advantage of the data is its comprehensive coverage of Canadian firms. It includes both manufacturing and service firms and both publicly-traded and (the more numerous) privately-held firms. While the service sector plays an important role in the Canadian economy, information on service firms is relatively scarce as compared to manufacturing firms. T2-LEAP includes both the very largest publicly-traded firms and relatively smaller privately-held firms in Canada. The inclusion of smaller firms is particularly important for the study of service firms given that the majority of service firms are small. In our sample, more than half of the firms have fewer than four employees. ${ }^{12} \mathrm{We}$ are restricted to book values of debt, equity, and assets. As noted above, the frequency of the data is annual. All financial data is converted to real (1986) Canadian dollars using the Consumer Price Index (CPI).

T2-LEAP is ideal for identifying entry/exit because it consists of the universe of Canadian firms. In the T2-LEAP data we can identify the year of birth (should the firm enter post 1984) and the year of death (should the firm exit prior to 1998). We use the criteria set out in Baggs (2005) for identifying entrants and exits. Specifically, a panel of survivors and exiters is constructed using the T2-LEAP data as follows. The initial population of firms we consider are those firms which existed in 1986. The sample

\footnotetext{
${ }^{10}$ An "establishment" is not necessarily equivalent to a "firm" as some large firms have multiple establishments, but the overwhelming majority of firms are single establishments and, correspondingly, the vast majority of establishments correspond to independent firms. We will use the term "firm" to represent the units in the data set from now on.

${ }^{11}$ The first (1984) and last (1998) years are dropped because they are partial years only. We use 1985 but when the data are lagged we end up with data from 1986-97.

${ }^{12}$ The mean firm has 22 employees and the median firm has just 4 employees.
} 
will be augmented in each consecutive year by removing exiting firms and adding new firms. A firm is removed from the sample in year $t$ if year $t$ is the year in which the firm files its last tax return (the T2SUF measure of exit) or if year $t$ is the last year in which the firm employs workers (the LEAP measure of exit). If a firm falls into either of these categories, it is counted as exiting. If a firm has missing data for some year(s) but then reappears in later years, the years of missing data are dropped from our analysis but the firm is not counted as exiting. When the firm reappears in the data it is added back into our unbalanced panel, but not counted as an entrant. ${ }^{13} \mathrm{~A}$ firm enters our sample in the first year it both employs workers and files a tax return.

\subsection{Exchange Rate Movements}

In order to estimate the effect of exchange rate movements on survival, the T2-LEAP data was linked to real exchange rate data at the 3-digit SIC level. In the 1980s and 1990s, the Canadian economy experienced large currency depreciations and appreciations. The value of Canadian dollar against the US dollar declined in the early 1980s and reached US\$ 0.69 on February 4, 1986. The value of Canadian dollar increased in the later half of the 1980 s until it peaked at US\$ 0.89 on November 4, 1991. The value of the Canadian dollar then decreased and reached the historic low of US\$ 0.63 on August 27, 1998, followed by a new cycle of currency appreciation. ${ }^{14}$

As the US is the most important export destination and import source for the Canadian manufacturing as well as service sectors, the value of the Canadian dollar with respect to the US dollar has a strong implication. However, industries are different in the composition of major trade partners; making it possible that exchange rate movements affect each industry to varying degrees. We construct industry-specific trade-weighted real exchange rates (TWRERs) to measure the industry-specific exchange rate movements. This variable is constructed using exchange rates, a price index (specific to each country) and the volume of service trade data between Canada and its major trade partners. ${ }^{15}$ The

\footnotetext{
${ }^{13}$ In the T2LEAP data set, each year approximately $2.8 \%$ of firms have missing data. The missing year phenomenon is likely caused by firms filing taxes late. Therefore, it is more appropriate to classify them as continuing firms.

${ }^{14}$ See Powell (2003).

${ }^{15}$ See the appendix for sources of exchange rate and price data.
} 
details of the methodology to construct the trade weighted real exchange rate have been summarized in Baggs et al (2009). In brief, the TWRER is constructed in three steps. First, the bilateral real exchange rates are normalized to avoid the unit problem in aggregation. ${ }^{16}$ Second, industry specific weights are constructed based on the sum of exports and imports from 1990 to 2000 for each 3-digit industry's ten largest trading partners. The shares and trade partners vary by industry, but not by year. Finally, the trade weighted real exchange rates (weighted by the trade shares specified above) are constructed for each industry and year (1984-1997). ${ }^{17}$

Data on volume of service trade by service type and country is from the Balance of Payments division from Statistics Canada. The service trade data is from 1990 to 2005 . We use the volume of trade (sum of imports and exports) from 1990 to 2000 to identify Canada's top 10 trade partners for each industry and construct the trade shares. We then concord the service types with Standard Industry Classification so that we can link the trade weighted real exchange rate to the firm-level data at SIC 3digit level.

Figure 1 presents the trade weighted real exchange rate from 1984 to 1997 . Since 1984 is used as the base year, the TWRER for all the industries are set to 100 in that year. Similar to the pattern observed in trade in manufacturing goods, the US is the most important import source as well as export destination. A large weight on trade with the United States makes the overall pattern of movements of the trade weighted real exchange rate resemble the movements of the bilateral Canada/US exchange rate: an appreciation from 1987 to 1991 followed by a six year depreciation from 1992 to 1997 . Note that the exchange rate variable is based on the average value for the year. The firm data, as described above, are based on observations over the year.

\footnotetext{
${ }^{16}$ The formula of TWRER follows Head and Ries (1999) and Bernard and Jensen (2004). The real exchange rates for each country are normalized using 1984 as the base year.

${ }^{17}$ Alternatively, we have constructed import or export weighted real exchange rates. Because of the similarity in the composition of import source and export destination countries between 1990 and 2000, the import or export weighted real exchange rates are highly correlated with the trade weighted real exchange rates.
} 
Figure 1: Trade Weighted Real Exchange Rate, 1984-1997

$1984=100$

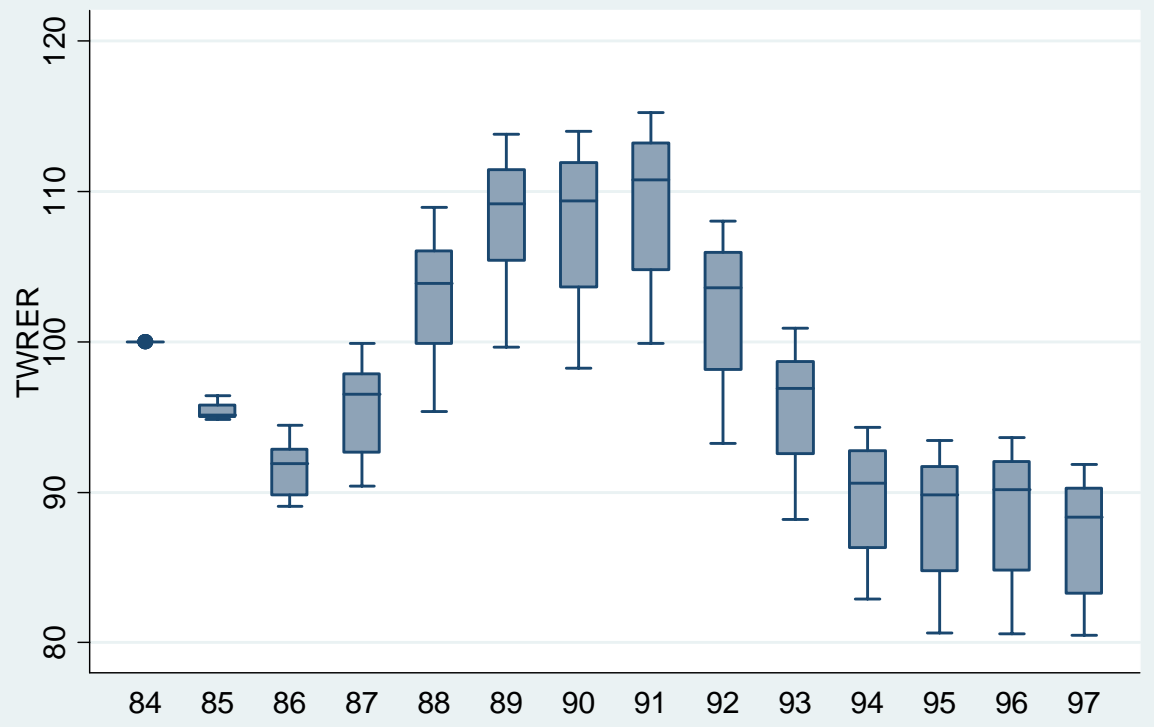

Our firm-level data set has over 817,217 firm-year observations. Table 1 contains descriptive statistics for three samples of firms. The first column is comprised of statistics for the complete sample of 817,217 firm-year observations. The second column contains only surviving firm-years and the third contains firms exiting at some point between 1986 and 1997. A total of 47,093 firms exited over this period. Column 4 indicates whether the mean value of each variable is significantly different for the population of survivors as compared to exiters, at the $5 \%$ level. We find that on average, exiting firms are significantly younger, smaller and have higher leverage than their surviving counterparts. They operate in more concentrated industries with higher rates of growth. Surprisingly, the exiters faced a slightly lower TWRER (0.292 smaller) and had higher labour productivity as compared to the survivors. On average, the difference between exiters and survivors are small in age and concentration ratio. Exiters are younger by 0.1 years and the concentration ratio is only very slightly higher for exiters -- a difference of 0.006 . However, the difference in the number of employees and leverage is large. The mean leverage of exiters is more than double that of survivors while they employ on average one-third as many people. In the next section we turn our attention to a more formalized model to test the implications of exchange rate movements for firm survival. 
Table 1 - Descriptive Statistics

\begin{tabular}{|lcccc|}
\hline \hline & & & & $\begin{array}{c}\text { Survivors } \\
\text { and Exits } \\
\text { significantly } \\
\text { different at } \\
\text { the 5\% } \\
\text { level? }\end{array}$ \\
\hline Number of Observations & All Firms & Survivors & Exits & \\
Mean TWR exchange rate & & & 47093 & Yes \\
Mean Enterprise Age (truncated at 14) & 817217 & 770124 & 97.269 & Yes \\
Mean Number of Employees (ALU*) & 97.544 & 97.561 & 6.144 & Yes \\
Mean Sales & 22.090 & 22.995 & 7.295 & Yes \\
Mean Sales per Worker & 2963501 & 3098151 & 761540 & Yes \\
Mean Leverage & 136494 & 129332 & 252993 & Yes \\
Mean Annual Industry Sales Growth (\%) & 6.310 & 6.292 & 6.600 & Yes \\
Mean four firm concentration ratio & 0.283 & 0.283 & 0.289 & Yes \\
\hline
\end{tabular}

*Employees are measured as "Average Labour Units" or ALU, interpreted as the number of "standardized employees" working for a firm during a year. A standardized employee corresponds to the industry-specific average (based on payroll data) across full-time and part-time workers.

\section{Empirical Analysis}

In this section, we empirically examine the effects of exchange rate movements on firm profitability, survival, and sales, as predicted in our three hypotheses above.

\subsection{Profits}

The first hypothesis specified in section 2 deals with the exchange rate effect on firm profits: an appreciation of Canadian dollar reduces the mark-up domestic firms are able to charge and accordingly lowers profits, a depreciation has the opposite affect. Owing to data limitations, we are unable to construct the economic profit. Here, we use the accounting profit reported in the T2-LEAP data as a proxy. The equation estimated can be specified as follows:

$$
\ln \text { profit }_{f t}=\beta_{1}+\beta_{2} \ln E R_{i t}+\not x_{f t-1}+\theta y_{i t-1}+\tau_{t}+\varepsilon_{f t},
$$

where $\ln$ rrofit $_{f t}$ is the logarithm of profit. In view of the skewness of profits it is appropriate to use the 
(natural) logarithm of profits as the dependent variable. $\operatorname{lnER}_{i t}$ is the logarithm of the industry-specific trade-weighted real exchange rate. $x_{f t-1}$ is a vector of firm characteristics that including age, size and productivity and $\tau_{t}$ is a time trend. $y_{i t-1}$ is a vector of industry level control variables including four-firm concentration ratio (CR4), real interest rate, and the logarithms of lagged industry sales and lagged Canadian real GDP. Firm size is indicated by size category and it is determined by the number of employees. ${ }^{18}$ The real interest rate, Canadian real GDP, a time trend and industry sales are used to control for changes in the macro environment.

In the first column of Table 2, estimation is with OLS, creating a benchmark. ${ }^{19}$ In the second column panel regression with fixed effects is used, showing qualitatively similar results. Columns 3 and 4 are estimated with a Tobit estimation procedure (with random effects) to deal with truncation in the profit data. ${ }^{20}$ Our profit data is truncated for two reasons. First, because taking the natural log of profits is not feasible for profits less than or equal to zero, ${ }^{21}$ and second, because of reporting issues for firms with non-positive profits. As detailed in Baggs and Brander (2006), since the underlying source data is firm tax records, most firms with negative profits have simply recorded a "zero" on their tax forms as they have no taxable profits. A small number of firms do report negative profits. Accordingly, we are unable to identify if recorded "zero" profits are indeed zero, or are in fact a loss, resulting in the only consistent profit data being for firms with positive profits. In columns 3 and 4, our Tobit estimation procedure is used where the natural log of profits for firm-years with zero or negative profits are coded as " 0 ", and the Tobit lower limit is set to " 0 " to account for the bundling of all negative profits as zeros.

\footnotetext{
${ }^{18}$ There are four size categories ( size $=1,2,3$, or 4 ). Size $=1$ if the number of employees is below 10 ; size $=2$ if between 10 and 50; size $=3$ if between 50 and 100 and $=4$ if above 100 .

${ }^{19}$ In the profits and sales OLS regressions, our sample is an unbalanced panel including all firms that survive to the end of a given year. If a firm exits in year $t$, it will not be included in our analysis in year $t$ or in subsequent years, but will be included in year $t-1$ and previous years. Including the profits and sales of firms in the year in which they exit is problematic because of partial year reporting (we can not differentiate between an exiting firm that operated for one week in year $t$ or 51 weeks in year $t$ ).

${ }^{20}$ In the fixed-effects regressions and Tobit with random effects, we exclude the surviving firms that are in the sample for less than three years.

${ }^{21}$ Here, negative or zero profits are replaced with 1 before taking logarithms.
} 
Table 2 - Firm Profits

Dependent Variable: $\ln$ (profit)

\begin{tabular}{|c|c|c|c|c|}
\hline & 1 & 2 & 3 & 4 \\
\hline $\begin{array}{l}\text { Trade Weighted Exchange Rate } \\
\text { (increase=appreciation of C\$), level: year } t\end{array}$ & $\begin{array}{c}-1.947 * * \\
(0.056)\end{array}$ & $\begin{array}{c}-1.217 * * \\
(0.035)\end{array}$ & $\begin{array}{c}-5.118 * * \\
(0.128)\end{array}$ & $\begin{array}{c}0.015 \\
(0.386)\end{array}$ \\
\hline $\begin{array}{l}\text { Exchange Rate*Productivity } \\
\quad=\text { Trade Weighted ER*Labour productivity }\end{array}$ & & & & $\begin{array}{c}-1.169^{* *} \\
(0.083)\end{array}$ \\
\hline $\begin{array}{l}\text { Labour Productivity } \\
\qquad=\ln \left(\text { sales }_{\mathrm{t}-1} / \mathrm{alu}_{\mathrm{t}-1}\right)\end{array}$ & $\begin{array}{c}0.521 * * \\
(0.005)\end{array}$ & $\begin{array}{l}0.157 * * \\
(0.005)\end{array}$ & $\begin{array}{l}1.033^{* *} \\
(0.012)\end{array}$ & $\begin{array}{c}6.383 * * \\
(0.380)\end{array}$ \\
\hline $\begin{array}{l}\text { Firm Size } \\
=1 \text { if alu } \\
=3 \text { if } 50<\text { alu }_{t-1} \leq 10,=2 \text { if } 10<\text { alu }_{t-1} \leq 50 ; \\
\text { if } \text { alu }_{\mathrm{t}-1}>100\end{array}$ & $\begin{array}{l}0.589 * * \\
(0.014)\end{array}$ & $\begin{array}{l}0.259 * * \\
(0.011)\end{array}$ & $\begin{array}{l}1.074 * * \\
(0.020)\end{array}$ & $\begin{array}{l}1.071 * * \\
(0.020)\end{array}$ \\
\hline $\begin{array}{l}\text { Age } \\
=\ln (\text { age in years })\end{array}$ & $\begin{array}{c}0.095^{* *} \\
(0.006)\end{array}$ & $\begin{array}{l}0.073 * * \\
(0.010)\end{array}$ & $\begin{array}{c}0.393 * * \\
(0.025)\end{array}$ & $\begin{array}{c}0.385^{* *} \\
(0.025)\end{array}$ \\
\hline $\begin{array}{l}\text { Industry Sales } \\
\text { Log of } 3 \text {-digit industry sales (year } \mathrm{t}-1 \text { ) excluding } \\
\text { firm f. }\end{array}$ & $\begin{array}{c}0.183 * * \\
(0.007)\end{array}$ & $\begin{array}{l}0.288 * * \\
(0.021)\end{array}$ & $\begin{array}{l}1.092 * * \\
(0.033)\end{array}$ & $\begin{array}{l}1.108 * * \\
(0.033)\end{array}$ \\
\hline $\begin{array}{l}\text { Industrial Concentration } \\
\text { 3-digit CR4 (year t-1) }\end{array}$ & $\begin{array}{c}0.843 * * \\
(0.046)\end{array}$ & $\begin{array}{c}-0.238^{* *} \\
(0.044)\end{array}$ & $\begin{array}{c}-0.742 * * \\
(0.107)\end{array}$ & $\begin{array}{c}-0.717 * * \\
(0.107)\end{array}$ \\
\hline $\begin{array}{l}\text { Canadian GDP } \\
\quad=\log \text { of Canadian real GDP (year t-1) }\end{array}$ & $\begin{array}{c}3.504 * * \\
(0.145)\end{array}$ & $\begin{array}{l}1.984 * * \\
(0.123)\end{array}$ & $\begin{array}{c}9.323 * * \\
(0.420)\end{array}$ & $\begin{array}{r}9.211^{* *} \\
(0.420)\end{array}$ \\
\hline $\begin{array}{l}\text { Real Interest Rate } \\
\qquad=\text { Canadian prime rate in year } \mathrm{t}\end{array}$ & $\begin{array}{l}0.011 * * \\
(0.002)\end{array}$ & $\begin{array}{c}-0.014 * * \\
(0.002)\end{array}$ & $\begin{array}{c}-0.045^{* *} \\
(0.008)\end{array}$ & $\begin{array}{c}-0.044 * * \\
(0.008)\end{array}$ \\
\hline $\begin{array}{l}\text { Time Trend } \\
\qquad=1 \text { if year=86, }=12 \text { if year }=97\end{array}$ & YES & YES & YES & YES \\
\hline $\begin{array}{l}\text { Industry Fixed Effects } \\
\text { two-digit SIC dummy variables }\end{array}$ & YES & NO & YES & YES \\
\hline Firm Fixed Effects & NO & YES & NO & NO \\
\hline $\mathrm{R}^{2} /$ Log Likelihood & 0.175 & 0.017 & -501378 & -501280 \\
\hline Observations & 736741 & 671513 & 671513 & 671513 \\
\hline Estimation Method & OLS & $\begin{array}{c}\text { Panel } \\
\text { Regression } \\
\text { with Fixed } \\
\text { Effects }\end{array}$ & $\begin{array}{l}\text { Random } \\
\text { Effect } \\
\text { Tobit }\end{array}$ & $\begin{array}{l}\text { Random } \\
\text { Effect } \\
\text { Tobit }\end{array}$ \\
\hline
\end{tabular}

$* *=$ significant at $1 \%, *=$ significant at $5 \%, \wedge=$ significant at $10 \%$.

Standard errors are in parentheses.

Robust standard errors (corrected for clustering at the firm level) are reported in columns 1 and 2. 
Consistent with our first hypothesis, the results show a negative relationship between a higher value of the domestic currency and profits, implying that a currency appreciation reduces firm profits and a depreciation increases profits. The negative relation between home currency appreciations and firm profit is in line with the findings in Baggs and Brander (2006) for the Canadian manufacturing sector. Turning attention to other variables, we find that larger, older and more productive firms have higher profits. At the industry level, firms have higher profits if their industries have higher sales. ${ }^{22}$ We also include industry fixed effects in columns 1, 3 and 4 . We control for the business cycle and macroeconomic shocks using the lagged annual Canadian real GDP, real interest rates and a time trend. Overall, profits increase with GDP and decrease with the interest rate.

In column 4, we investigate the possibility of a differing exchange rate effect for firms with different productivity levels by including a term interacting the exchange rate with labour productivity. Surprisingly, the results indicate that the negative effect of currency appreciation is more pronounced for more productive firms. One possible explanation is that more productive (and larger) firms serve larger markets and are subject to more intensive international competition while less productive (and smaller) firms serve the local market and their profits are accordingly less affected.

\subsection{Survival}

Having found a significant effect of the exchange rate on profits, we test our second hypothesis concerning the effect of the exchange rate on survival using the following estimating equation:

$$
P\left(\text { survive }_{f t}\right)=\Phi\left(\beta_{1}+\beta_{2} \ln E R_{i t}+\not x_{f t-1}+\theta y_{i t-1}+\tau_{t}\right),
$$

where $f$ indexes firms and $i$ industries. survive $f t$ is a 0-1 dummy indicating whether enterprise $f$ was still alive at the end of year $t$ and estimation is by probit. Control variables are as specified for equation (1), with the addition of lagged leverage at the firm level. ${ }^{23}$ Standard errors are robust clustered by firm. The results of this estimation can be found in Table 3 .

\footnotetext{
${ }^{22}$ To prevent an endogeneity problem, in the firm-level regressions, the industry sales are defined as the sum of sales of all the firms in this industry except firm $f$.

${ }^{23}$ Here, the industry sales and Canadian GDP are in growth rates.
} 
Table 3 - Firm Survival

Dependent Variable: $=1$ if firm survives to end of year t, 0 otherwise, Estimation Method: Probit

\begin{tabular}{|c|c|c|c|c|}
\hline & 1 & 2 & 3 & 4 \\
\hline $\begin{array}{l}\Delta \text { Trade Weighted Exchange Rate } \\
\quad \text { (increase=appreciation of C\$), year t-year t-1 }\end{array}$ & & $\begin{array}{l}-0.532 * * \\
(0.072)\end{array}$ & & $\begin{aligned}-1.701 * * \\
(0.231)\end{aligned}$ \\
\hline $\begin{array}{l}\text { Trade Weighted Exchange Rate } \\
\text { (increase=appreciation of C\$), level: year } \mathrm{t}\end{array}$ & $\begin{array}{c}-0.180 * * \\
(0.038)\end{array}$ & & $\begin{array}{c}-0.516^{* *} \\
(0.114)\end{array}$ & \\
\hline $\begin{array}{l}\Delta \text { Exchange Rate*Productivity } \\
\quad=\Delta \text { Trade Weighted ER } * \text { Labour productivity }\end{array}$ & & & & $\begin{array}{l}0.295 * * \\
(0.055)\end{array}$ \\
\hline $\begin{array}{l}\text { Exchange Rate*Productivity } \\
=\text { Trade Weighted ER*Labour productivity }\end{array}$ & & & $\begin{array}{c}0.085^{* *} \\
(0.027)\end{array}$ & \\
\hline $\begin{array}{l}\text { Labour Productivity } \\
\quad=\ln \left(\operatorname{sales}_{t-1} / a_{u_{t-1}}\right)\end{array}$ & $\begin{array}{c}0.087 * * \\
(0.003)\end{array}$ & $\begin{array}{c}0.087 * * \\
(0.003)\end{array}$ & $\begin{array}{l}-0.301^{*} \\
(0.125)\end{array}$ & $\begin{array}{c}0.090 * * \\
(0.003)\end{array}$ \\
\hline $\begin{array}{l}\text { Leverage } \\
\qquad=\ln \left(\text { leverage }_{t-1}\right)\end{array}$ & $\begin{array}{c}-0.092 * * \\
(0.003)\end{array}$ & $\begin{array}{c}-0.092 * * \\
(0.003)\end{array}$ & $\begin{array}{c}-0.092 * * \\
(0.003)\end{array}$ & $\begin{array}{c}-0.092^{* *} \\
(0.003)\end{array}$ \\
\hline $\begin{array}{l}\text { Firm Size } \\
=1 \text { if } \text { alu }_{\mathrm{t}-1} \leq 10,=2 ; \text { if } 10<\mathrm{alu}_{\mathrm{t}-1} \leq 50 ; \\
=3 \text { if } 50<\text { alu }_{\mathrm{t}-1} \leq 100 ;=4 \text { if } \text { alu }_{\mathrm{t}-1}>100\end{array}$ & $\begin{array}{l}0.146^{* *} \\
(0.005)\end{array}$ & $\begin{array}{c}0.146^{* *} \\
(0.005)\end{array}$ & $\begin{array}{r}0.146^{* *} \\
(0.005)\end{array}$ & $\begin{array}{c}0.147 * * \\
(0.005)\end{array}$ \\
\hline $\begin{array}{l}\text { Age } \\
\quad=\ln (\text { age in years })\end{array}$ & $\begin{array}{c}-0.060 * * \\
(0.003)\end{array}$ & $\begin{array}{c}-0.059 * * \\
(0.003)\end{array}$ & $\begin{array}{c}-0.060^{* *} \\
(0.003)\end{array}$ & $\begin{array}{c}-0.060 * * \\
(0.003)\end{array}$ \\
\hline $\begin{array}{l}\text { Industry Sales Growth } \\
\% \text { growth in sales from yr } t-1 \text { to yr } t \text {, 3-digit SIC }\end{array}$ & $\begin{array}{l}-0.003 \\
(0.012)\end{array}$ & $\begin{array}{c}0.002 \\
(0.012)\end{array}$ & $\begin{array}{l}-0.003 \\
(0.012)\end{array}$ & $\begin{array}{c}0.003 \\
(0.012)\end{array}$ \\
\hline $\begin{array}{l}\text { Industrial Concentration } \\
\text { 3-digit CR4 (year t-1) }\end{array}$ & $\begin{array}{c}-0.329 * * \\
(0.021)\end{array}$ & $\begin{array}{c}-0.322 * * \\
(0.021)\end{array}$ & $\begin{array}{c}-0.329 * * \\
(0.021)\end{array}$ & $\begin{array}{c}-0.325^{* *} \\
(0.021)\end{array}$ \\
\hline $\begin{array}{l}\text { Canadian GDP } \\
\quad=\text { Canadian GDP growth (year } \mathrm{t}-1)\end{array}$ & $\begin{array}{l}-0.324 * \\
(0.153)\end{array}$ & $\begin{array}{l}0.279^{\wedge} \\
(0.146)\end{array}$ & $\begin{array}{r}-0.314^{*} \\
(0.153)\end{array}$ & $\begin{array}{l}0.291^{*} \\
(0.146)\end{array}$ \\
\hline $\begin{array}{l}\text { Real Interest Rate } \\
\quad=\text { Canadian prime rate in year } \mathrm{t}\end{array}$ & $\begin{array}{l}0.009 * * \\
(0.003)\end{array}$ & $\begin{array}{l}-0.005 \\
(0.003)\end{array}$ & $\begin{array}{c}0.009 * * \\
(0.003)\end{array}$ & $\begin{array}{l}-0.006 \\
(0.003)\end{array}$ \\
\hline $\begin{array}{l}\text { Time Trend } \\
\qquad=1 \text { if year }=86,=12 \text { if year }=97\end{array}$ & YES & YES & YES & YES \\
\hline $\begin{array}{l}\text { Industry Fixed Effects } \\
\text { two-digit SIC dummy variables }\end{array}$ & YES & YES & YES & YES \\
\hline Log Likelihood & -168864 & -168849 & -168858 & -168832 \\
\hline Observations & 779262 & 779262 & 779262 & 779262 \\
\hline
\end{tabular}

$* *=$ significant at $1 \%, *=$ significant at $5 \%, \wedge=$ significant at $10 \%$.

Robust standard errors (corrected for clustering at the firm level) are in parentheses. 
In all four specifications, the trade weighted real exchange rate is negatively and significantly related to firm survival. In the first and third columns the exchange rate is measured in levels, and in the second and fourth columns it is measured as the change in the level. Accordingly, our results indicate that both higher levels and appreciations of the Canadian dollar significantly reduce the probability of survival for Canadian service sector firms. This is consistent with our second hypothesis. Survival is also positively associated with firm labour productivity and size, and negatively associated with leverage and age. The age result is quite surprising. ${ }^{24}$ At the industry level, a firm is more likely to survive if it operates in an industry where the four largest firms account for a smaller share of total sales. The real interest rate is insignificant in determining survival when the change of the exchange rate is considered, but positive and significant when the level of exchange rate is used. In addition, we also find that the growth of Canadian GDP is positively associated with survival when the change of the exchange rate is used.

To explore the possibility that firm responses to exchange rates are heterogeneous based on their other attributes, the third and fourth columns interact the exchange rate with labour productivity. The interaction is positive and significant indicating that appreciations reduce the probability of survival, but this effect is smaller for firms with higher labour productivity. This result is similar to arguments in the trade liberalization literature, see for example Melitz (2003) and Melitz and Ottaviano (2008), where increased competition from falling tariffs leads to the exit of firms with lower productivity. Given that currency appreciations act to hamper the competition position of domestic firms in both the domestic and foreign markets, this result is qualitatively similar. We see lower productivity firms less able to survive in an environment where currency appreciation gives foreign firms a cost advantage. Note that the demise of low productivity firms in the face of appreciation increases the average productivity within an industry and may contribute to a productivity improvement at the industry level. This is again analogous to the trade liberalization induced industry level productivity improvement described in Melitz and Ottaviano

\footnotetext{
${ }^{24}$ The surprising negative coefficient estimates for the firm age variable may result from the age being truncated (at 14 years) and the logarithmic form of this variable. A substantial number of surviving firms are one-year old, making the average logarithm of age for surviving firms smaller. In alternative regressions, we use age in years instead of logarithm and the age effect becomes positive.
} 
(2008), and in Bernard et. al. (2003).

Like our profit results, the survival results are qualitatively similar to results for manufacturing firms. Using the same data set, Baggs et. al. (2009), find the survival of manufacturing firms to be negatively and significantly affected by currency appreciations, and this effect tends to be smaller for more productive firms. While not completely comparable as the specifications differ slightly, it is also interesting to note that overall the coefficients of the exchange rate terms in this paper are only slightly smaller in magnitude to those found for manufacturing firms in Baggs et. al. (2009). This suggests that exchange rate changes not only have significant implications for service firms, but also that these implications may not be all that much smaller than those in more traditionally "traded" sectors. We explore this further in section 5 below.

\subsection{Sales}

The third hypothesis deals with the effect of the exchange rate on firm sales. Given that the exit rate in the Canadian service sector is low, it is likely that the influence of the exchange rate on the relative cost of domestic products as compared with foreign will dominate and therefore a real appreciation will reduce the sales of non-exiting firms. A real depreciation is expected to have the opposite effect. We investigate the implications of currency movements for firm sales by applying the following estimating equation to an un-balanced panel of surviving firms:

$$
\ln \text { sales }_{f t}=\beta_{1}+\beta_{2} \ln E R_{i t}+\gamma x_{f t-1}+\theta y_{i t-1}+\tau_{t}+\varepsilon_{f t},
$$

To avoid an endogeneity problem, where industry sales are used as a control variable, it is measured using the total sales of the industry minus the sales of firm $f$. We have estimated equation (3) using OLS and panel regression with fixed effects. The results are reported in Table 4.

Our results show a negative and significant effect of a currency appreciation on the sales of surviving firms, which is consistent with the predictions of Fung's (2008) model when the exit and entry rates are low. This suggests that, when the Canadian dollar appreciates, the revenue lost due to foreign competition and lower prices outweighs any possible gain in market share as a result of exit. Conversely, 
during periods of depreciation, incumbent firms are able to expand their sales, despite increased entry. This is consistent with Forbes (2002) who finds that firms in countries that have experienced devaluations have higher output and operating profit growth and with Baggs et al (2009) who find a negative effect of currency appreciation on the sales of Canadian manufacturing firms.

Table 4 - Firm Sales

\begin{tabular}{|c|c|c|}
\hline & lnsales & lnsales \\
\hline & 1 & 2 \\
\hline $\begin{array}{l}\text { Trade Weighted Exchange Rate } \\
\text { (increase=appreciation of C\$), level: year } t\end{array}$ & $\begin{array}{c}-1.185^{* *} \\
(0.029)\end{array}$ & $\begin{array}{c}-0.888^{* *} \\
(0.018)\end{array}$ \\
\hline $\begin{array}{l}\text { Leverage } \\
\qquad=\ln \left(\text { leverage }_{t-1}\right)\end{array}$ & $\begin{array}{r}0.086^{* *} \\
(0.003)\end{array}$ & $\begin{array}{c}0.073 * * \\
(0.003)\end{array}$ \\
\hline $\begin{array}{l}\text { Firm Size } \\
=1 \text { if } \text { alu }_{\mathrm{t}-1} \leq 10,=2 ; \text { if } 10<\mathrm{alu}_{\mathrm{t}-1} \leq 50 \\
=3 \text { if } 50<\text { alu }_{\mathrm{t}-1} \leq 100 ;=4 \text { if } \mathrm{alu}_{\mathrm{t}-1}>100\end{array}$ & $\begin{array}{l}1.521 * * \\
(0.007)\end{array}$ & $\begin{array}{c}0.374 * * \\
(0.005)\end{array}$ \\
\hline $\begin{array}{l}\text { Age } \\
=\ln (\text { age in years })\end{array}$ & $\begin{array}{c}0.067 * * \\
(0.004)\end{array}$ & $\begin{array}{c}0.073 * * \\
(0.005)\end{array}$ \\
\hline $\begin{array}{l}\text { Industry Sales } \\
\text { Log of 3-digit industry sales (year t-1) excluding } \\
\text { firm f. }\end{array}$ & $\begin{array}{c}0.146^{* *} \\
(0.004)\end{array}$ & $\begin{array}{r}0.302 * * \\
(0.012)\end{array}$ \\
\hline $\begin{array}{l}\text { Industrial Concentration } \\
\text { 3-digit CR4 (year t-1) }\end{array}$ & $\begin{array}{c}-0.108 * * \\
(0.022)\end{array}$ & $\begin{array}{c}-0.560 * * \\
(0.025)\end{array}$ \\
\hline $\begin{array}{l}\text { Canadian GDP } \\
\quad=\text { Canadian real GDP }(\text { year t }-1)\end{array}$ & $\begin{array}{c}3.181 * * \\
(0.083)\end{array}$ & $\begin{array}{c}2.454 * * \\
(0.061)\end{array}$ \\
\hline $\begin{array}{l}\text { Real Interest Rate } \\
\quad=\text { Canadian prime rate in year } \mathrm{t}\end{array}$ & $\begin{array}{c}-0.006 * * \\
(0.001)\end{array}$ & $\begin{array}{c}-0.005 * * \\
(0.001)\end{array}$ \\
\hline $\begin{array}{l}\text { Time Trend } \\
\quad=1 \text { if year=86, }=12 \text { if year }=97\end{array}$ & YES & YES \\
\hline $\begin{array}{l}\text { Industry Fixed Effects } \\
\text { two-digit SIC dummy variables }\end{array}$ & YES & NO \\
\hline Firm Fixed Effects & NO & YES \\
\hline $\mathrm{R}^{2}$ & 0.448 & 0.054 \\
\hline Observations & 731075 & 666868 \\
\hline Estimation Method & OLS & $\begin{array}{l}\text { Panel } \\
\text { Regression } \\
\text { with Fixed } \\
\text { Effects } \\
\end{array}$ \\
\hline
\end{tabular}

$* *=$ significant at $1 \%, *=$ significant at $5 \%, \wedge=$ significant at $10 \%$.

Robust standard errors (corrected for clustering at the firm level) are in parentheses. 
Turning our attention to control variables, we find a positive association between older and larger firms and sales. ${ }^{25}$ Interestingly, we see that firms with higher leverage have higher sales, implying that firms may expand sales by raising debt. At the industry level, sales are positively associated with industry level sales and Canadian GDP, and negatively associated with industrial concentration and increases in the interest rate.

\section{Discussion of Results}

\subsection{Comparison between Service and Manufacturing Sector Firms}

Our findings indicate that the exchange rate effect on the profits, survival and sales of service sector firms are in the same direction as those for manufacturing firms discussed in Baggs et al (2009) and Baggs and Brander (2006). However, the magnitude of the exchange rate effects are not directly comparable given that the models used in this paper are slightly different from the ones used in those papers. As the T2LEAP contains both service and manufacturing firms, we are able to re-estimate equations (1) to (3) using manufacturing firms. The results are reported in Table 5. In Table 5, columns 1, 3 and 5 duplicate results for the profits, survival and sales of service sector firms as reported in Tables 2, 3 and $4 .{ }^{26}$ Columns 2, 4 and 6 estimate the same specifications for manufacturing firms. ${ }^{27}$

For all three dependent variables the sign and significance of the exchange rate term is the same for firms in the service and manufacturing sectors. For the case of profits, the coefficient of the exchange rate term is significantly larger for the manufacturing sector. This is not surprising, as we would expect profits in the manufacturing sector, with its considerable export orientation and exposure to foreign competition, to be more affected by exchange rates than the less traded service sector. Interestingly, for

\footnotetext{
${ }^{25}$ Since we can only measure productivity using labour productivity (sales per worker), endogeneity issues prevent us from including labour productivity as an independent variable when sales is the dependent variable.

${ }^{26}$ For profits, the results are from column 2 of Table 2 . For survival, the results are from column 1 of Table 3 and, for sales, the results are from column 2 of Table 4.

${ }^{27}$ Note that for the manufacturing firms, another important determinant of firm survival and performance in this period is the tariff concessions mandated by the Canada-US FTA. As we do not have reliable tariff data for service sector firms, for our comparison purposes, these tariffs are also excluded from the manufacturing estimates. To ensure that this exclusion was not un-duly influencing our results, we re-estimated the same specifications reported in Table 5 with tariffs included for manufacturing firms (full results available from authors upon request). The coefficient estimates for the exchange rate variable are very close to those reported here.
} 
Table 5 - Services and Manufacturing Comparison

\begin{tabular}{|c|c|c|c|c|c|c|}
\hline Dependent Variable & Profit & Profit & Survival & Survival & Sales & Sales \\
\hline & 1 & 2 & 3 & 4 & 5 & 6 \\
\hline Sector & Services & Manufacturing & Services & Manufacturing & Services & Manufacturing \\
\hline $\begin{array}{l}\text { Trade Weighted } \\
\text { Exchange Rate }\end{array}$ & $\begin{array}{c}-1.217 * * \\
(0.035)\end{array}$ & $\begin{array}{c}-4.384 * * \\
(0.064)\end{array}$ & $\begin{array}{c}-0.180^{* *} \\
(0.038)\end{array}$ & $\begin{array}{c}-0.117 * * \\
(0.054)\end{array}$ & $\begin{array}{c}-0.888 * * \\
(0.018)\end{array}$ & $\begin{array}{c}-1.195^{* *} \\
(0.022)\end{array}$ \\
\hline Labour Productivity & $\begin{array}{l}0.157 * * \\
(0.005)\end{array}$ & $\begin{array}{c}0.296 * * \\
(0.011)\end{array}$ & $\begin{array}{c}0.087 * * \\
(0.003)\end{array}$ & $\begin{array}{c}0.111 * * \\
(0.005)\end{array}$ & & \\
\hline Leverage & & & $\begin{array}{c}-0.092 * * \\
(0.003)\end{array}$ & $\begin{array}{c}-0.294 * * \\
(0.007)\end{array}$ & $\begin{array}{c}0.073 * * \\
(0.003)\end{array}$ & $\begin{array}{c}0.064 * * \\
(0.006)\end{array}$ \\
\hline Firm Size & $\begin{array}{c}0.259 * * \\
(0.011)\end{array}$ & $\begin{array}{c}0.468 * * \\
(0.012)\end{array}$ & $\begin{array}{c}0.146 * * \\
(0.005)\end{array}$ & $\begin{array}{c}0.102 * * \\
(0.005)\end{array}$ & $\begin{array}{c}0.374 * * \\
(0.005)\end{array}$ & $\begin{array}{c}0.405 * * \\
(0.005)\end{array}$ \\
\hline Age & $\begin{array}{c}0.073 * * \\
(0.010)\end{array}$ & $\begin{array}{c}0.396 * * \\
(0.019)\end{array}$ & $\begin{array}{c}-0.060 * * \\
(0.003)\end{array}$ & $\begin{array}{c}-0.059 * * \\
(0.006)\end{array}$ & $\begin{array}{c}0.073 * * \\
(0.005)\end{array}$ & $\begin{array}{c}0.203 * * \\
(0.008)\end{array}$ \\
\hline Industry Sales & $\begin{array}{c}0.288 * * \\
(0.021)\end{array}$ & $\begin{array}{c}0.172 * * \\
(0.030)\end{array}$ & $\begin{array}{l}-0.003 \\
(0.012)\end{array}$ & $\begin{array}{c}0.133 * * \\
(0.028)\end{array}$ & $\begin{array}{c}0.302 * * \\
(0.012)\end{array}$ & $\begin{array}{c}0.223 * * \\
(0.011)\end{array}$ \\
\hline $\begin{array}{l}\text { Industrial } \\
\text { Concentration }\end{array}$ & $\begin{array}{c}-0.238 * * \\
(0.044)\end{array}$ & $\begin{array}{l}-0.036 \\
(0.076)\end{array}$ & $\begin{array}{c}-0.329 * * \\
(0.021)\end{array}$ & $\begin{array}{c}-0.073 * * \\
(0.028)\end{array}$ & $\begin{array}{c}-0.560 * * \\
(0.025)\end{array}$ & $\begin{array}{c}-0.334 * * \\
(0.028)\end{array}$ \\
\hline Canadian GDP & $\begin{array}{c}1.984 * * \\
(0.123)\end{array}$ & $\begin{array}{c}4.348 * * \\
(0.231)\end{array}$ & $\begin{array}{c}-0.324^{*} \\
(0.153)\end{array}$ & $\begin{array}{c}0.233 \\
(0.231)\end{array}$ & $\begin{array}{c}2.454 * * \\
(0.061)\end{array}$ & $\begin{array}{c}2.419 * * \\
(0.075)\end{array}$ \\
\hline Real Interest Rate & $\begin{array}{c}-0.014 * * \\
(0.002)\end{array}$ & $\begin{array}{c}-0.040 * * \\
(0.003)\end{array}$ & $\begin{array}{c}0.009 * * \\
(0.003)\end{array}$ & $\begin{array}{c}0.017 * * \\
(0.005)\end{array}$ & $\begin{array}{c}-0.005^{* *} \\
(0.001)\end{array}$ & $\begin{array}{c}-0.024 * * \\
(0.001)\end{array}$ \\
\hline Time Trend & YES & YES & YES & YES & YES & YES \\
\hline $\begin{array}{l}\text { Industry Fixed } \\
\text { Effects }\end{array}$ & NO & NO & YES & YES & NO & NO \\
\hline Firm Fixed Effects & YES & YES & NO & NO & YES & YES \\
\hline $\mathrm{R}^{2} /$ Log Likelihood & 0.017 & 0.084 & -168864 & -70262 & 0.054 & 0.118 \\
\hline Observations & 671513 & 341107 & 779262 & 375996 & 666868 & 340011 \\
\hline Estimation Method & $\begin{array}{c}\text { Panel } \\
\text { Regression } \\
\text { with Fixed } \\
\text { Effects }\end{array}$ & $\begin{array}{c}\text { Panel } \\
\text { Regression } \\
\text { with Fixed } \\
\text { Effects }\end{array}$ & Probit & Probit & $\begin{array}{c}\text { Panel } \\
\text { Regression } \\
\text { with Fixed } \\
\text { Effects }\end{array}$ & $\begin{array}{c}\text { Panel } \\
\text { Regression } \\
\text { with Fixed } \\
\text { Effects }\end{array}$ \\
\hline
\end{tabular}

$* *=$ significant at $1 \%, *=$ significant at $5 \%, \wedge=$ significant at $10 \%$.

Robust standard errors (corrected for clustering at the firm level) are reported in parentheses. 
survival, this result is reversed, and for sales there is little difference between the exchange rate coefficient for services and manufacturing. A possible explanation for these differences is the difference in average size between service and manufacturing firms. Service firms are substantially smaller, and perhaps accordingly more vulnerable to exit as a result of any negative stimuli (including unfavourable exchange rate movements). Turning our attention to the control variables, we note that most are of the same sign and significance for both sectors, though magnitudes vary. The exceptions to this are industrial concentration (negative and significant for the profits of service firms, insignificant for manufacturing) and Canadian GDP growth (negative and significant for the survival of service firms, insignificant for the survival of manufacturing firms).

Overall, however, service sector firms are significantly affected by exchange rate movements and this affect is similar, though not identical, to that observed for manufacturing firms. In the next subsection we further compare the consequences of exchange rate movements for both service and manufacturing firms by exploring the economic magnitude of these effects.

\subsection{Economic Significance}

So far, we have found a statistically significant exchange rate effect on the profits, survival and sales for service sector firms. As the next step to understand the impact of exchange rate movements, we analyze the economic significance by computing the predicted value of each dependent variable with different values of the exchange rate, while all other variables at their mean levels. In our sample period, the annual average value of Canadian dollar peaked in 1991 and reached its lowest level in 1997. Table 6 summarizes the predicted values of profits, probability of survival and sales, using the specifications reported in Table 5 and different values of the trade weighted real exchange rate (TWRER). The first row of each section reports the predicted values when all variables are at their means, the second row shows the predicted value with the highest observed TWRER (109.15) and all other variables at their means, and the third row with the lowest values of TWRER (87.20) and all other variables at their means. Comparing the predicted values for service and manufacturing firms, we see that in all cases, service firms are 
smaller in terms of profits and sales and have a lower rate of survival than manufacturing firms.

Table 6 - Predicted Economic Effects of Exchange Rates

\begin{tabular}{|c|c|c|c|c|c|c|}
\hline & Profits & Profits & $\begin{array}{l}\text { Probability } \\
\text { of Survival }\end{array}$ & $\begin{array}{c}\text { Probability of } \\
\text { Survival }\end{array}$ & Sales & Sales \\
\hline Sector & Services & Manufacturing & Services & Manufacturing & Services & Manufacturing \\
\hline At Mean Values & $\$ 2,776$ & $\$ 89,492$ & 0.945 & 0.957 & $\$ 297,355$ & $\$ 897,166$ \\
\hline Highest TWRER & & & & & & \\
\hline $\begin{array}{l}1991 \text { Exchange Rate } \\
(\text { TWRER=109.15) }\end{array}$ & $\$ 2,422$ & $\$ 49,854$ & 0.943 & 0.955 & $\$ 269,169$ & $\$ 764,859$ \\
\hline Lowest TWRER & & & & & & \\
\hline $\begin{array}{l}1997 \text { Exchange Rate } \\
(\text { TWRER=87.20) }\end{array}$ & $\$ 3,182$ & $\$ 133,301$ & 0.947 & 0.957 & $\$ 328,482$ & $\$ 1,000,120$ \\
\hline
\end{tabular}

For service sector firms, when the exchange rate moves from mean levels to its highest value, profits fall by $13 \%$, sales by $9 \%$ and the probability of survival in a given year falls slightly, from $94.5 \%$ to $94.3 \%$. For manufacturing firms, the move from the mean to the highest levels of the exchange rate reduces profits by an astounding $44 \%$, sales by $15 \%$ and the probability of survival falls from $95.7 \%$ to 95.5\%. Moving from the highest values of TWRER to the lowest observed in our sample period (from the second row to the last row in Table 6), we see a considerable improvement in all three outcomes in both sectors. Comparing the highest value of the exchange rate to the lowest, service sector firms see their profits improve by $31 \%$, sales by $22 \%$, and the probability of survival rise from $94.3 \%$ to $94.7 \%$. Manufacturing firms see their profits almost triple, a 31\% increase in sales and a small increase in the probability of survival from $95.5 \%$ to $95.7 \%$.

The size of the calculated effects is quite large. This is perhaps not surprising for manufacturing firms, but is more unexpected for the service sector. These results suggest that service sector firms are significantly affected by international economic conditions, and underscore the importance of including 
services when considering the effects of changes in the international competitive environment on domestic industries. Note that while we are looking at a very large change in the exchange rate (the difference between a TWRER of 109.15 at its highest to 87.20 at its lowest, or a $25 \%$ depreciation over 6 years), swings of this magnitude over this sort of time frame are not unusual. More recently, between January and November of 2007 alone, the Canadian dollar appreciated approximately $20 \%$ against the US dollar.

Like the statistical results in the previous sub-section, the economic magnitude calculations suggest that when facing identical exchange rate changes (from the highest to the lowest value of the Canadian dollar), the profit changes among manufacturing firms are substantially larger than the reaction of service sector firms. Where the regression results suggest similar responses for the sales of firms in either sector, our economic calculations suggest that the response of sales is indeed larger for manufacturing firms. Interestingly, the change in service firms' probability of survival in response to variation in the value of Canadian dollar is larger than the change in manufacturing firms. These results are consistent with Campbell and Lapham's (2004) findings that retail trade firms adjust more at the extensive margin (the number of establishments) while manufacturing firms adjust more at the intensive margin (the size of establishments) when faced with exchange rate fluctuations.

\section{Conclusions}

In this paper, we find significant implications of real exchange rate fluctuations for firms in the Canadian service sector. The exchange rate affects the profits, survival and sales of service sector firms in the same direction found for the manufacturing sector in other studies. Appreciations of the domestic currency reduce survival, particularly for less productive firms, and lower the sales of non-exiting firms. Exchange rate fluctuations also significantly affect the profits of service sector firms. For the case of profits and sales, the magnitude of the implications of exchange rate fluctuations is substantially smaller for service sector firms than for manufacturing. However, the probability of survival of service sector firms is more affected by exchange rate changes than manufacturing firms. 
These significant findings are of particular note as the service sector has often been excluded from studies of international economics based on the argument that they are non-traded and hence should be unaffected. This paper suggests that even though the service sector remains among the "least traded" sectors of the economy, it is still significantly impacted by exchange rate fluctuations.

This paper provides much needed empirical research on the influence of large real exchange rate movements on plant (firm) survival, sales, and profitability. Since it is among the first micro-level empirical studies on this topic, results from this paper not only can be of the interest of academic researchers but also can be potentially valuable for policy makers when evaluating the long-run impact on the service sector of the large depreciation of the Canadian dollar in the last decade and of the recent appreciation. 


\section{Appendix: Data Sources}

The nominal exchange rate of various countries (against the US dollar) is obtained from the International Financial Statistics and the World Development Indicators. The exchange rates against the US dollar were then converted to the exchange rates of foreign currency units per Canadian dollar. The country specific price used for the construction of real exchange rate is GDP deflator and it is from the World Development Indicators. The nominal interest rate used for the construction of real interest rate is the Government of Canada benchmark bond yields (10-year) and it was then deflated using GDP deflator. The measure of Canadian GDP is GDP in 1992 constant dollars (in millions). Both nominal interest rate and Canadian GDP are from the CANSIMII database. 


\section{References}

Baggs, J. (2005) "Firm Survival and Exit in Response to Trade Liberalization", Canadian Journal of Economics 38(4): 1364-1383.

Baggs, J., E. Beaulieu and L. Fung (2009) "Firm Survival, Performance and the Exchange Rate," Canadian Journal of Economics, 42(2): 393-421.

Baggs, J. and J. Brander (2006) “Trade Liberalization and Financial Leverage," Journal of International Business Studies, 37(2): 196-211.

Baldwin, R. and P. Krugman (1989). "Persistent Trade Effects of Large Exchange Rate Shocks." The Quarterly Journal of Economics 104(4): 635-654.

Bergin, P. and Feenstra, R. (2001) "Pricing to Market, Staggered Prices and Real Exchange Rate Persistence”, Journal of International Economics, 54(2): 333-359.

Bergin, P. and Feenstra, R. (2000) "Staggered Price Setting and Endogenous Persistence," Journal of Monetary Economics 45 (3): 657-680.

Bernard, A. B. and J. B. Jensen (2004) "Entry, Expansion, and Intensity in the U.S. Export Boom, 19871992." Review of International Economics 12(4): 662-675.

Bernard, A. B., J. Eaton, J. B. Jensen and S. Kortum (2003) "Plants and Productivity in International Trade." American Economic Review 93(4): 1268-1290.

Campbell, J. R. and B. Lapham (2004) "Real Exchange Rate Fluctuations and the Dynamics of Retail Trade Industries on the U.S.-Canada border," American Economic Review 94 (4): 1194-1206.

Clarida, R. (1991) “The Real Exchange Rate, Exports, and Manufacturing Profits: A Theoretical Framework with some Empirical Support," NBER working paper 3811.

Copeland, B. R. (2002) "Benefits and costs of trade and investment liberalization in services: Implications from trade theory," Trade Policy Research 2002, http://www.dfaitmaeci.gc.ca/eet/research/TPR_2002-en.asp

Feenstra, R. (1989) "Symmetric Pass-Through of Tariffs and Exchange Rates under Imperfect Competition: An Empirical Test." Journal of International Economics 27 (1/2): 25-45.

Feenstra, R. (2003) 'A homothetic utility function for monopolistic competition models, without constant price elasticity,' Economics Letters 78, 79-86.

Foote, C. L. (1998). "Trend Employment Growth and the Bunching of Job Creation and Destruction." Quarterly Journal of Economics 113(3): 809-834.

Forbes, K. J. (2002) 'Cheap labor meets costly capital: the impact of devaluations on commodity firms,' Journal of Development Economics 69, 335-365.

Fung, L. (2008) "Large Real Exchange Rate Movements, Firm Dynamics, and Productivity Growth," Canadian Journal of Economics 41(2): 391-424. 
Head, K. and J. Ries (1999) "Rationalization Effects of Tariff Reductions," Journal of International Economics, 47(2): 295-320.

Krugman, P. (1979) "Increasing Returns, Monopolistic Competition, and International Trade," Journal of International Economics, 9(4): 469-479.

Lewis-Bynoe, D., J. Griffith, and W. Moore (2002) "Trade Liberalization and the Manufacturing Sector: The Case of the Small Developing Country," Contemporary Economic Policy, 20(2): 272-287.

Melitz, M. J. (2003) "The Impact of Trade on Intra-industry Reallocations and Aggregate Industry Productivity.” Econometrica 71(6): 1695-1725.

Melitz, M. J. and G. I. P. Ottaviano (2008) 'Market size, trade, and productivity,' Review of Economic Studies 75, 295-316

Mann, C. L. (1986) "Prices, Profit Margins and the Exchange Rate", Federal Reserve Bulletin, June: $366-$ 379.

Pavcnik, N. (2002) "Trade Liberalization, Exit, and Productivity Improvements: Evidence from Chilean Plants.” Review of Economics Studies, 69, 245-276.

Powell, J. (2003) A History of the CANADIAN DOLLAR. Bank of Canada.

UNCTAD (2004) World Investment Report: The Shift Toward Services. (United Nations: New York). 